\title{
Re-thinking about prophylactic cranial irradiation for small cell lung cancer in the MRI era
}

\author{
Aiko Ouchi ${ }^{1}$, Young Hak Kim ${ }^{1}$, Shigeaki Iwatsubo ${ }^{1}$, Yoshihiro Nishimura ${ }^{2}$, Yasuhiro Funada ${ }^{1}$ \\ ${ }^{1}$ Department of Respiratory Medicine, Takatsuki General Hospital, Takatsuki, Osaka, Japan; ${ }^{2}$ Department of Respiratory Medicine, Graduate School \\ of Medicine, Kobe University, Kobe, Japan \\ Correspondence to: Young Hak Kim, MD, PhD. Department of Respiratory Medicine, Takatsuki General Hospital, 1-3-13 Kosobe-cho, Takatsuki, \\ Osaka 569-1192, Japan. Email: ykim.free@gmail.com.
}

Submitted May 24, 2021. Accepted for publication Jul 29, 2021.

doi: $10.21037 /$ jtd-21-870

View this article at: https://dx.doi.org/10.21037/jtd-21-870

Decline of neurocognitive function is a major concern in the treatment with whole brain radiotherapy (WBRT), and it is also the case with prophylactic cranial irradiation (PCI). A previous study suggested the efficacy of memantine, an $\mathrm{N}$-methyl-D-aspartate (NMDA) receptor antagonist, in the preservation of neurocognitive function after WBRT (1); however, more effective approach has been required eagerly. Hippocampus avoidance (HA)-WBRT is a newly developed radiation technique which can limit radiation dose to the bilateral hippocampus, and better preservation of neurocognitive function compared with standard WBRT has been reported previously (2). NCT01780675 is a phase III randomized trial of PCI with or without HA technique in small-cell lung cancer (SCLC), and the results of the trial were recently published in the Fournal of Thoracic Oncology (3). In the study, a total of 168 patients with SCLC who completed chemo (radio) therapy were randomized to receive standard PCI or HA-PCI of 25 Gy in 10 fractions. HA-PCI did not increase the risk of brain metastases including hippocampus and did not show negative impact on survival compared with standard PCI; however, HAPCI failed to prevent the decline of neurocognitive function compared with standard PCI. As a result, this was a negative study. Nevertheless, the study provided us an opportunity to re-think about PCI for SCLC.

For extensive stage (ES)-SCLC, an European study conducted by European Organization for Research and Treatment of Cancer (EORTC) reported the results supporting PCI. However, screening or follow-up of brain metastases using brain MRI was not mandatory in the study (4). Subsequently, a Japanese phase III study demonstrated that PCI deteriorates survival compared with a periodic follow-up with brain MRI, and the negative impact on quality-of-life due to prolonged anorexia and nausea after PCI was considered to be a primary reason (5). A following retrospective study also support the follow-up strategy instead of PCI (6), and practice pattern has changed in this setting (7). In addition, PCI is not superior to MRI surveillance from the aspect of cost-effectiveness (8). Thus, on the premise of regular follow-up with brain MRI, PCI is no longer a standard treatment for ES-SCLC. If HA-PCI were to be investigated in randomized studies in future, the standard arm should be a regular follow-up with brain MRI.

The decline of cognitive function after PCI is more problematic in limited stage (LS)-SCLC, because patients with LS-SCLC generally live quite longer than patients with ES-SCLC (9). For patients with LS-SCLC who achieved complete response after chemoradiotherapy, PCI has been the standard treatment for a long time (10). However, the significance of PCI for LS-SCLC in the MRI era is still uncertain. In fact, the MD Anderson Cancer Center Group conducted a retrospective analysis including 297 patients with LS-SCLC (205 received PCI and 92 did not) and revealed that PCI was not significantly associated with overall survival (11). The results of ongoing SWOG 1827 (NCT04155034), a randomized phase III trial comparing PCI with MRI surveillance and MRI surveillance alone in patients with SCLC, might redefine the role of PCI for patients with LS-SCLC in the MRI era and increase the importance of avoiding neurocognitive deterioration. In that sense, the development of new radiation techniques, including HA-PCI, should be continued. 


\section{Acknowledgments}

Funding: None.

\section{Footnote}

Provenance and Peer Review: This article was a standard submission to the journal. The article has undergone external peer review.

Peer Review File: Available at https://dx.doi.org/10.21037/ jtd-21-870

Conflicts of Interest: All authors have completed the ICMJE uniform disclosure form (available at https://dx.doi. org/10.21037/jtd-21-870). The authors have no conflicts of interest to declare.

Ethical Statement: The authors are accountable for all aspects of the work in ensuring that questions related to the accuracy or integrity of any part of the work are appropriately investigated and resolved.

Open Access Statement: This is an Open Access article distributed in accordance with the Creative Commons Attribution-NonCommercial-NoDerivs 4.0 International License (CC BY-NC-ND 4.0), which permits the noncommercial replication and distribution of the article with the strict proviso that no changes or edits are made and the original work is properly cited (including links to both the formal publication through the relevant DOI and the license). See: https://creativecommons.org/licenses/by-nc-nd/4.0/.

\section{References}

1. Brown PD, Pugh S, Laack NN, et al. Memantine for the prevention of cognitive dysfunction in patients receiving whole-brain radiotherapy: a randomized, double-blind, placebo-controlled trial. Neuro Oncol 2013;15:1429-37.

2. Brown PD, Gondi V, Pugh S, et al. Hippocampal Avoidance During Whole-Brain Radiotherapy Plus Memantine for Patients With Brain Metastases: Phase III Trial NRG Oncology CC001. J Clin Oncol 2020;38:1019-29.

3. Belderbos JSA, De Ruysscher DKM, De Jaeger K, et al. Phase 3 Randomized Trial of Prophylactic Cranial Irradiation With or Without Hippocampus Avoidance in
SCLC (NCT01780675). J Thorac Oncol 2021;16:840-9.

4. Slotman B, Faivre-Finn C, Kramer G, et al. Prophylactic cranial irradiation in extensive small-cell lung cancer. $\mathrm{N}$ Engl J Med 2007;357:664-72.

5. Takahashi T, Yamanaka T, Seto T, et al. Prophylactic cranial irradiation versus observation in patients with extensive-disease small-cell lung cancer: a multicentre, randomised, open-label, phase 3 trial. Lancet Oncol 2017;18:663-71.

6. Keller A, Ghanta S, Rodríguez-López JL, et al. Utility of Prophylactic Cranial Irradiation for Extensive-Stage Small-Cell Lung Cancer in the MRI Screening Era. Clin Lung Cancer 2021. [Epub ahead of print]. doi: 10.1016/ j.cllc.2021.03.009.

7. Gjyshi O, Ludmir EB, Pezzi TA, et al. Evolving Practice Patterns in the Use of Prophylactic Cranial Irradiation for Extensive-Stage Small Cell Lung Cancer. JAMA Netw Open 2019;2:e199135.

8. Kim H, Keller A, Beriwal S, et al. Cost-Effectiveness of Prophylactic Cranial Irradiation Versus MRI Surveillance for Extensive-Stage Small Cell Lung Cancer. Int J Radiat Oncol Biol Phys 2021. [Epub ahead of print]. doi: 10.1016/ j.ijrobp.2021.04.049.

9. Le Péchoux C, Laplanche A, Faivre-Finn C, et al. Clinical neurological outcome and quality of life among patients with limited small-cell cancer treated with two different doses of prophylactic cranial irradiation in the intergroup phase III trial (PCI99-01, EORTC 22003-08004, RTOG 0212 and IFCT 99-01). Ann Oncol 2011;22:1154-63.

10. Aupérin A, Arriagada R, Pignon JP, et al. Prophylactic cranial irradiation for patients with small-cell lung cancer in complete remission. Prophylactic Cranial Irradiation Overview Collaborative Group. N Engl J Med 1999;341:476-84.

11. Pezzi TA, Fang P, Gjyshi O, et al. Rates of Overall Survival and Intracranial Control in the Magnetic Resonance Imaging Era for Patients With Limited-Stage Small Cell Lung Cancer With and Without Prophylactic Cranial Irradiation. JAMA Netw Open 2020;3:e201929.

Cite this article as: Ouchi A, Kim YH, Iwatsubo S, Nishimura Y, Funada Y. Re-thinking about prophylactic cranial irradiation for small cell lung cancer in the MRI era. J Thorac Dis 2021;13(8):5115-5116. doi: 10.21037/jtd-21-870 